\title{
Effect of provenances on wood properties of Balfourodendron riedelianum
}

\section{Efecto de las proveniencias en propiedades de la madera de Balfourodendron riedelianum}

\author{
Amanda Aparecida Vianna Assad', Adriano Wagner Ballarin², Miguel Luiz Menezes Freitas ${ }^{3}$ and \\ Eduardo Luiz Longui ${ }^{*}$
}

2 Universidade Estadual Paulista. Faculdade de
Ciências Agronômicas. Botucatu, São Paulo, Brazil.

\author{
3 Instituto Florestal. Divisão de Dasonomia. São Paulo, \\ Brazil.
}

* Corresponding author. edulongui@gmail.com

\begin{abstract}
Wood is comparatively more conservative than other parts of trees, such as leaves, which present greater phenotypic plasticity. We studied the effect of seed origin on annual increment, physical-mechanical properties and anatomical characteristics of Balfourodendron riedelianum wood in a homogeneous plantation (Luiz Antônio Experimental Station (LAES)) from three natural provenances (Gália and Bauru in São Paulo State and Alvorada do Sul in Paraná State, Brazil). Because genotypic information is a determinant of wood formation, trees were expected to develop wood structure based on their provenances. Our results demostrate that variations in volume, properties and wood anatomy were influenced by provenance. Alvorada do Sul trees showed lower growth in volume and higher strength and homogeneity, compared to Gália and Bauru. Typical radial pattern was not observed for most characteristics, except modulus of elasticity and fiber length in Gália and compression parallel to the grain in Bauru that increased towards the bark. Based on the latter characteristc, B. riedelianum wood in a homogeneous planting has class C40 mechanical strength, as indicated for use in medium-sized structures, light civil construction and the manufacture of furniture.
\end{abstract}

KEYWORDS: annual increment, guatambú, pau marfim, radial variation, strength class, tropical wood.

\section{RESUMEN}

La madera es comparativamente más conservadora que otras partes de los árboles, como las hojas, que presentan una mayor plasticidad fenotípica. Se estudió el efecto del origen de la semilla sobre el incremento anual, las propiedades físico-mecánicas y las características anatómicas de la madera de Balfourodendron riedelianum en una plantación homogénea (LAES) de tres procedencias (Gália y Bauru en Estado de São Paulo y Alvorada do Sul en Estado de Paraná, Brasil). Debido a que la información genotípica es un determinante de la formación de la madera, se esperaba que los árboles desarrollaran una estructura de madera basada en sus genética de las procedencias. Los resultados de este estudio demuestran que las variaciones en volumen, propiedades y anatomía de la madera fueron influenciadas por la procedencia. Los árboles de Alvorada do Sul mostraron menor crecimiento en volumen y, por lo tanto, mayor resistencia y homogeneidad, en comparación con Gália y Bauru. El patrón radial típico no fue observado para la mayoría de las características, excepto el módulo de la elasticidad y la longitud de la fibra en Gália y la compresión paralela al grano en Bauru que aumentó en dirección a la corteza. Con base en esta última característica, la madera de B. riedelianum en plantación homogénea tiene una resistencia mecánica de clase C40, tal como se indica para su uso en estructuras medianas, construcción civil ligera y fabricación de muebles.

PALABRAS CLAVE: incremento anual, guatambú, pau marfim, variación radial, clase de resistência, madera tropical. 


\section{INTRODUCTION}

Plants, like all living beings, have the ability to adapt to different demands of the environments. Wood is comparatively more conservative than other parts of trees, such as leaves, which present greater phenotypic plasticity. We know that genotypic information is a determinant of wood formation. Therefore, it is expected that trees with different provenances, though growing in the same place (different from seed origins), will still develop wood structure based on the genetic information from environmental origin conditions (Longui et al., 2011). To test this idea, we studied the effect of seed origin on annual increment, physical-mechanical properties and anatomical characteristics from three provenances of Balfourodendron riedelianum wood growing together in Luiz Antônio, Brazil. B. riedelianum (Engler) Engler (Rutaceae), popularly known as pau marfim or guatambú, is a native, nonendemic species of Brazil with geographical distribution in midwestern, southeastern and southern Brazil, as well as the Cerrado and Atlantic Forest (Pirani, Groppo, \& Dias, 2017). The species also occurs in Argentina and Paraguay, and the major threat arises from overexploitation of timber and deforestation. Accordingly, it has been identified as "endangered" (International Union for Conservation of Nature and Natural Resources - IUCN, 1998).

Timber produced in a sustainable manner on a worldwide scale is of great interest in order to reduce the pressure on native forests. Over the last decades, a large supply of commercial timber has come from the Brazilian Amazon Forest (Zenid et al., 2009), but such harvesting has endangered the conservation of this biome. Thus, to avoid the predatory wood cutting, consumption should be deliberate, and production should be acquired from companies able to prove tree origin through a management plan and the necessary documentation to comply with pertinent forestry laws (Zenid et al., 2009). This same concern should be adopted for timber from all Brazilian biomes. Thus, research that enables producers to comply with these conditions is essential.
In this context, the Instituto Florestal de São Paulo, Brazil, has promoted studies with several native forest species with economic potential, e.g., from of provenance and progeny tests, base populations and seed orchards to $e x$ situ conservation and production of seedlings for decades (Gurgel Garrido, Faria, Cruz, \& Palomo, 1997). Among the studied species, we highlight $B$. riedelianum, which has ornamental use, as well as use for reforestation (Durigan, Figliolia, Kawabata, Garrido, and Baitello, 1997). Based on its excellent wood quality, Paula and Alves (2007) report that $B$. riedelianum wood has long been used in civil construction, carpentry, furniture manufacture and other applications. Despite the importance of B. riedelianum for logging purposes, we have little knowledge about the effects of large-scale cultivation and no detailed information on productivity, cultivation techniques, or the growth and development of a natural genetic variant available for breeding. Thus, as described above, our study with provenance tests in adult age (30 years age) and considering silvicultural and wood traits, represents a unique opportunity to increase such knowledge by collecting seeds from three natural populations and in a homogeneous plantation.

\section{OBJECTIVES}

This study proposal was to estimate effect of provenances on tree volume, volume per hectare and mean annual increment of $B$. riedelianum. To determine variations in properties and anatomy in function of provenances and radial variation. Finally, to characterize physical-mechanical properties to know wood strength and strength class. In this way, providing information for farmers interested in planting B. riedelianum.

\section{MATERIALS AND METHODS}

\section{Provenances of the seeds and planting area}

In 1983, seeds from open-pollinated plants were collected in three natural populations (provenances) of B. riedelianum in the states of São Paulo and Paraná municipalities, Gália, Bauru, and Alvorada do Sul. Seedlings were grown up from 
seeds planted in 1984 at the Luiz Antônio Experimental Station (LAES), in municipality of Luiz Antônio. Geographic location, clima and soil data from the four areas are presented in table 1 . The plantation was established in six blocks in linear plots of six plants at a spacing of $3 \mathrm{~m} \times$ 3 m (Gurgel-Garrido et al., 1997).

\section{Mean annual increment}

In 2015, dbh - diameter at breast height, of about 1400 trees was measured with caliper, and height was measured with a hypsometer Vertex IV. From dbh and height values the volume was calculated based on the formula proposed by Higuchi (1978). The equation used was

$$
\text { Volume }=0.063+0.255 \times \text { Diameter } \times \text { Height }
$$

Then, the volume per hectare was calculated considering the spacing $(3 \mathrm{~m} \times 3 \mathrm{~m})$ and the number of plants. The number of plantas was multiplied by the average tree volume. Finally, the volume per hectare and year was calculated by dividing volume per hectare by age of planting (30 years).

\section{Sampling for physical and mechanical properties and anatomical features}

We cut 36 randomly selected trees, 12 from each provenance. A trunk log of $1.3 \mathrm{~m}$ was removed from the base of each tree, and a central plank was cut to obtain specimens for physical and mechanical properties and anatomical characteristics. Three radial positions were established: the nearest part of trunk center, which was designated as pith, a middle position, and a position close to the bark, which was designated as bark.

TABLE 1. Geographic location, climatic and soil data in provenance test of B. riedelianum (Gália-SP, Bauru-SP and Alvorada do Sul-PR) at 30 years old in municipality of Luiz Antônio-SP.

\begin{tabular}{|c|c|c|c|c|}
\hline Area and Geographic location & $\begin{array}{c}\text { Luiz Antônio } \\
\left(21^{\circ} 40^{\prime} S, 47^{\circ} 49^{\prime} W\right)\end{array}$ & $\begin{array}{c}\text { Gália } \\
\left(22^{\circ} 17^{\prime} S, 49^{\circ} 33^{\prime} W\right)\end{array}$ & $\begin{array}{c}\text { Bauru } \\
\left(22^{\circ} 18^{\prime} S, 49^{\circ} O 3^{\prime} W\right)\end{array}$ & $\begin{array}{l}\text { Alvorada do Sul } \\
\left(22^{\circ} 46^{\prime} \mathrm{S}, 51^{\circ} 13^{\prime} \mathrm{W}\right)\end{array}$ \\
\hline $\begin{array}{l}\text { Köppen climate } \\
\text { classification }\end{array}$ & Cwa & Cwa & Cwa & $\mathrm{Cfa}$ \\
\hline Mean precipitation $(\mathrm{mm})^{*}$ & 1340 & 1395 & 1296 & 1368 \\
\hline Mean temperature $\left({ }^{\circ} \mathrm{C}\right)^{*}$ & 23.5 & 22.0 & 22.5 & 22.1 \\
\hline $\begin{array}{l}\text { Mean minimum temperature } \\
\left({ }^{\circ} \mathrm{C}\right)\end{array}$ & 16 & 15.6 & 17.2 & 16 \\
\hline $\begin{array}{l}\text { Mean maximum temperature } \\
\left({ }^{\circ} \mathrm{C}\right)\end{array}$ & 30 & 28.5 & 27.8 & 28.4 \\
\hline Altitude $(\mathrm{m})$ & 550 & 650 & 530 & 320 \\
\hline Soil type and characteristic ${ }^{* *}$ & $\begin{array}{l}\text { Dark Red Latosol. } \\
\text { Medium texture, } \\
\text { clayey or very clayey. } \\
\text { High fertility. Low } \\
\text { water holding } \\
\text { capacity. }\end{array}$ & $\begin{array}{l}\text { Red Yellow Latosol. } \\
\text { Medium texture. Low } \\
\text { fertility. Low water } \\
\text { holding capacity. }\end{array}$ & $\begin{array}{l}\text { Red Argisols. } \\
\text { Medium texture to } \\
\text { course. Low } \\
\text { fertility. Low water } \\
\text { holding capacity. }\end{array}$ & $\begin{array}{l}\text { Red nitosol. Clayy } \\
\text { texture to very } \\
\text { clayey. Medium to } \\
\text { high fertility. High } \\
\text { water holding } \\
\text { capacity. }\end{array}$ \\
\hline
\end{tabular}

* Sistema de Informação Hidrológicas / Agência Nacional de Águas [ANA] (2017), Data of mean annual precipitation and temperature from January 1975 to December 1985. ** Data of Luiz Antônio, Gália, Bauru, and Alvorada do Sul were reported by Zanatto, Leonel, Thomaziello, and Oliveira (2O13), ESALQ-USP (2006), Almeida, Toniato, and Durigan (2O11), and Bhering et al. (2007), respectively. 


\section{Apparent density (D12)}

Apparent density was determined in acclimatized specimens by the ratio of their mass and volume at the current moisture content (MC). We used the model proposed by Rezende, Escobedo, and Ferraz (1988) based on the study of Kollmann and Côté (1968) to obtain the value to nominal 12\% equilibrium moisture content (EMC) $\left(\mathrm{D}_{12}\right)$ (see Eq. 1). The density of the model used at any moisture content $\left(\mathrm{D}_{\mathrm{u} \%}\right.$, ranging from $0 \%$ to $\left.25 \% \mathrm{MC}\right)$ is relative to the density at $0 \% \mathrm{MC}\left(\mathrm{D}_{0}\right)$. Then, $\mathrm{D}_{12}$ was calculated from $\mathrm{D}_{0}$ using the two equations:

$$
\begin{gathered}
D_{u \%}=D_{0}\left(1+0.01_{u \%}\right)\left(1-\frac{0.0084_{u \%} D_{0}}{1+0.28 D_{0}}\right) \\
D_{12 \%}=\frac{1.12 D_{0}+0.2007 D_{0}^{2}}{1+0.28 D_{0}}
\end{gathered}
$$

\section{Mechanical tests}

We carried out the following tests: shear strength parallel to grain, compression strength parallel to grain, modulus of elasticity and rupture in bending. Tests were performed in a computer-controlled $300 \mathrm{kN}$ eletromechanical testing machine. Strains were evaluated using a standard mechanical strain gauge extensometer (accuracy of 0.001 $\mathrm{mm})$.

Mechanical tests were performed according to NBR 7190 (Associação Brasileira de Normas Técnicas [ABNT]
1997). We used a loading speed of $2.5 \mathrm{MPa} / \mathrm{min}$ (shear strength) and $10.0 \mathrm{MPa} / \mathrm{min}$ (compression and bending). Initial results of strength and elastic properties (modulus of elasticity) were corrected to the EMC (12\%) using a conversion coefficient of $3 \%$ (of variation per $1 \%$ of $\mathrm{MC}$ variation) for strength properties and $2 \%$ for elastic properties.

In the Brazilian standard NBR 7190 (ABNT, 1997), the characteristic value of compression strength parallel to grain is used to classify the wood in the system of strength classes (Table 2), and it guides the choice of the most suitable species for structural projects.

\section{Anatomical analysis}

We cut small portions of wood from each sample for maceration using Franklin's method (Berlyn and Miksche, 1976). Wood fragments were stained with aqueous safranin and mounted temporarily in a solution of water and glycerin (1:1). Samples of $2 \mathrm{~cm}^{3}$ were softened in boiling water and glycerin (4:1) for $1 \mathrm{~h}$ to $2 \mathrm{~h}$. From these samples, transverse and longitudinal sections $18-25 \mu \mathrm{m}$ in thickness were obtained with a sliding microtome. Sections were bleached with sodium hypochlorite $(60 \%)$, washed thoroughly in water, and stained with 1\% safranin (Johansen, 1940). Measurements followed the recommendations of the IAWA Committee (IAWA, 1989). Quantitative data are based on at least 25 measurements for each characteristic from each tree, thus fulfilling statistical requirements for the minimum number of measurements.

TABLE 2. Strength classes and characteristic values for hardwoods at $12 \% \mathrm{MC}$, based on the NBR 7190.

\begin{tabular}{cccccc}
\hline \multicolumn{6}{c}{ Hardwoods } \\
\hline Classes & $\sigma_{c l, k}(\mathrm{MPa})$ & $\sigma_{s, k}(\mathrm{MPa})$ & $E_{c, m}(\mathrm{MPa})$ & $D_{b}\left(\mathrm{~g} \mathrm{~cm}^{-3}\right)$ & $D_{12}\left(\mathrm{~g} \mathrm{~cm}^{-3}\right)$ \\
\hline C20 & 20 & 4 & 9500 & 0.500 & 0.650 \\
C30 & 30 & 5 & 14500 & 0.650 & 0.800 \\
C40 & 40 & 6 & 19500 & 0.750 & 0.950 \\
C60 & 60 & 8 & 24500 & 0.800 & 1.000 \\
\hline
\end{tabular}

$\sigma_{\mathrm{cl}, \mathrm{k}}=$ Compression parallel to the grain. $\sigma_{\mathrm{s}, \mathrm{k}}=$ volumetric shrinkage. $E_{\mathrm{cl}, \mathrm{m}}=$ modulus of elasticity $\cdot D_{\mathrm{b}}=$ basic density $\cdot D_{12}=a p p a r e n t ~ d e n s i t y$. 


\section{Data analysis}

We initially undertook descriptive statistical analysis and used Box Plot graphics to detect outliers. Thus, values 1.5 times higher than the 3 rd quartile and values 1.5 times lower than the 1st quartile were excluded from the analysis. Normality tests were performed to check the distribution of data, and when a normal distribution was not observed, data were square root-transformed. Then, a parametric analysis of variance (one-way analysis of variance [ANOVA]) was performed. When a significant difference was observed between radial positions and provenances, Tukey's test was used to identify pairs of significantly different means. We analyzed the radial variation within the same tree and also three radial positions together comparing the provenances. Pearson's correlations between variables and variables with radial position were carried out.

\section{RESULTS AND DISCUSSION}

We observed larger dbh in Gália and Bauru, while tree height did not differ among the three provenances. Tree volume, volume per hectare and mean annual increment were higher in Bauru/Gália than Alvorada do Sul (Table 3).

With the exception of shear parallel to the grain in Gália and Alvorada do Sul, compression parallel to the grain in Gália and MOE in Alvorada do Sul, the other wood properties varied from pith toward the bark in the three provenances (Table 4). Considering the average among three radial positions, Alvorada do Sul presented higher density and compression parallel to the grain. Shear parallel to the grain was higher in Alvorada do Sul with no difference compared to Bauru. Gália and Alvorada do Sul showed higher values of MOE and MOR, and in the latter Alvorada do Sul did not differ from Bauru (Table 4).

Fiber diameter and wall thickness in Gália, vessel diameter and ray frequency in Bauru, and fiber width, diameter and wall thickness in Alvorada do Sul did not vary radially. The other anatomical characteristics showed variation (Table 5). Among provenances, shorter vessel elements occurred in Alvorada do Sul. Larger vessels were noticed in Bauru compared to the other two provenances. Gália showed less vessel frequency than other provenances. No variation was noted among provenances in ray height. Larger rays occurred in Gália, with no variation in Bauru. Higher ray frequency occurred in Gália. Fiber length increased gradually from pith to bark in Gália. It was longer in the middle position in Bauru and in middle and bark positions in Alvorada. Longer fibers occurred in Gália, with no difference to Alvorada do Sul. Larger fiber diameter occurred in Gália, with no difference to Bauru. Fiber wall thickness did not vary among the three provenances (Table 5).

TABLE 3. Silvicultural data and mean annual increment in provenance test of B. riedelianum (Gália-SP, Bauru-SP and Alvorada do Sul-PR) at 30 years old in municipality of Luiz Antônio-SP.

\begin{tabular}{|c|c|c|c|}
\hline & \multicolumn{3}{|c|}{ Provenances } \\
\hline & Gália & Bauru & Alvorada do Sul \\
\hline $\mathrm{dbh}(\mathrm{cm})$ & $6(16.36 a) 32$ & 4 (16.48a) 32 & 4 (15.19b) 26 \\
\hline Height (m) & $4(16.24 a) 26$ & 2 (15.95a) 27 & $3(15.64 a) 23$ \\
\hline Tree volume $\left(\mathrm{m}^{3}\right)$ & $0.06(0.18 a) 0.58$ & $0.06(0.19 a) 0.53$ & $0.06(0.16 b) 0.41$ \\
\hline Volume per hectare $\left(\mathrm{m}^{3} \mathrm{ha}^{-1}\right)$ & 209.62 & 213.90 & 185.18 \\
\hline Mean annual increment $\left(\mathrm{m}^{3} \mathrm{ha}^{-1}\right.$ year $\left.^{-1}\right)$ & 6.76 & 6.90 & 5.97 \\
\hline
\end{tabular}

Minimum (mean) and maximum values for dbh, height and tree volume are presented. In the same row, distinct letters differ statistically (P < O.05) by Tukey's test. 
TABLE 4. Physical and mechanical properties in provenance test of B. riedelianum (Gália-SP, Bauru-SP and Alvorada do Sul-PR) at 30 years old in municipality of Luiz Antônio-SP.

\begin{tabular}{|c|c|c|c|c|c|}
\hline \multicolumn{6}{|c|}{ Gália } \\
\hline Radial position & $D_{12}$ & $f_{v O}$ & $f_{c O}$ & MOE & MOR \\
\hline Pith & $0.87 a$ & $16.70 a$ & $44.89 a$ & $11801 \mathrm{~b}$ & $105.14 b$ \\
\hline Bark & $0.82 b$ & $18.52 a$ & $47.53 a$ & $14226 a$ & $129.32 a$ \\
\hline Mean & $0.84 B$ & $17.97 \mathrm{~B}$ & $46.68 C$ & $13056 A$ & $120.19 A B$ \\
\hline Middle & $0.87 a$ & $18.12 b$ & 49.18ab & $12464 a$ & $121.37 a$ \\
\hline Bark & $0.83 b$ & $20.28 a$ & $51.73 a$ & $11819 a$ & $123.77 a$ \\
\hline Mean & $0.84 \mathrm{~B}$ & $18.63 \mathrm{AB}$ & 49.07B & $11659 B$ & $116.56 \mathrm{~B}$ \\
\hline \multicolumn{6}{|c|}{ Alvorada do Sul } \\
\hline Pith & $0.90 b$ & $19.47 a$ & $50.56 b$ & $12622 a$ & $114.17 \mathrm{~b}$ \\
\hline
\end{tabular}

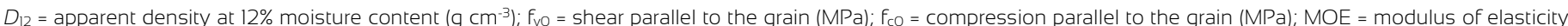

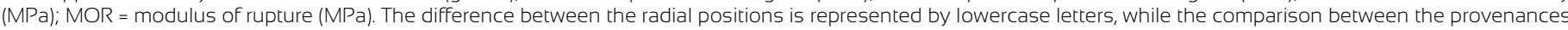
is represented by uppercase letters. In the same column, distinct letters differ statistically ( $P<0.05)$ by Tukey's test.

TABLE 5. Anatomical features in provenance test of B. riedelianum (Gália-SP, Bauru-SP and Alvorada do Sul-PR) at 30 years old in municipality of Luiz Antônio-SP.

\begin{tabular}{|c|c|c|c|c|c|c|c|c|c|}
\hline \multicolumn{10}{|c|}{ Gália } \\
\hline $\begin{array}{l}\text { Radial } \\
\text { position }\end{array}$ & VEL & $V D$ & $V F$ & $R H$ & $R W$ & $R F$ & $F L$ & $F D$ & $F W T$ \\
\hline Pith & $302 b$ & $48 b$ & $45 a$ & $215 b$ & $28 b$ & 7.0a & $1128 c$ & 15.1a & $4.7 a$ \\
\hline Middle & 319b & $51 a$ & $42 b$ & $216 b$ & 30a & $7.0 a$ & $1257 b$ & $15.4 a$ & $4.7 a$ \\
\hline Bark & $347 a$ & $49 b$ & $46 a$ & $235 a$ & $31 a$ & $6.5 b$ & $1325 a$ & $15.0 a$ & $4.7 a$ \\
\hline Mean & $321 \mathrm{~A}$ & $50 B$ & $44 B$ & $221 \mathrm{~A}$ & $30 A$ & $6.8 A$ & $1240 A$ & $15.2 \mathrm{~A}$ & $4.7 \mathrm{~A}$ \\
\hline \multicolumn{10}{|c|}{ Bauru } \\
\hline Pith & $290 b$ & $54 a$ & $45 b$ & $214 a$ & $28 b$ & $6.4 a$ & $1128 b$ & 15.1a & $4.5 b$ \\
\hline Middle & $324 a$ & $54 a$ & $44 b$ & $224 a$ & $30 a$ & $6.4 a$ & 1280a & $14.2 b$ & $4.6 a b$ \\
\hline Bark & $336 a$ & $53 a$ & $53 a$ & $227 a$ & $29 a b$ & $6.6 a$ & $1181 b$ & $15.3 a$ & $4.8 a$ \\
\hline Mean & $312 A$ & $53 \mathrm{~A}$ & $47 A$ & $220 A$ & $29 A B$ & $6.4 \mathrm{~B}$ & $1193 B$ & $14.8 \mathrm{AB}$ & $4.6 A$ \\
\hline \multicolumn{10}{|c|}{ Alvorada do Sul } \\
\hline Pith & $284 a b$ & $47 b$ & $47 a b$ & $208 b$ & $28 a$ & $6.1 a$ & $1167 b$ & $14.6 a$ & $4.5 a$ \\
\hline Middle & $306 a$ & $50 a$ & 45b & $225 a$ & $29 a$ & $6.0 a$ & $1238 a$ & $14.5 a$ & $4.7 a$ \\
\hline Bark & $299 b$ & 49ab & $48 a$ & 219ab & $29 a$ & $6.3 a$ & $1265 a$ & $14.5 a$ & $4.6 a$ \\
\hline Mean & 295B & $49 B$ & $46 A$ & $217 A$ & $28 B$ & $6.1 \mathrm{C}$ & $1216 A B$ & $14.5 B$ & $4.6 A$ \\
\hline
\end{tabular}

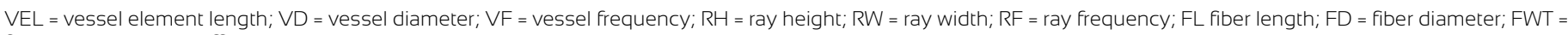

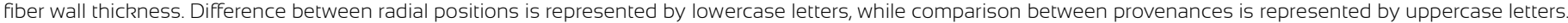
In the same column, distinct letters differ statistically $(P<0.05)$ by Tukey's test. 


\section{Effect of provenance on growth}

The increment difference among provenances may be associated with climate type and soil characteristics. Data in table 1 show that Alvorada do Sul (Cfa) has a different climate compared to other provenances and the planting area (Cwa), although precipitation and temperature means do not show much difference. It is possible that water holding capacity contributed to the results because Alvorada do Sul soil presents high water holding capacity, and plants were adapted to this condition, while in Gália, Bauru and Luiz Antônio, soil has low water holding capacity. Climate and soil differences may have influenced growth in this species, leading to a smaller increment in Alvorada do Sul compared to other provenances.

Consequently, lower growth in Alvorada do Sul, also described by Sebbenn, Freitas, Zanatto, Moraes, and Moraes (2007) for B. riedelianum in the same area as that of the present investigation, should be related to denser wood compared to Gália and Bauru. King, Davies, Nur Supardi, and Stan (2005), studying the relationship among tree growth, light absorption and wood density in Malaysian forests, reported a negative relationship between wood volume for a given biomass unit and its density. According to Harris (1981), faster growth of Gymnosperm or Angiosperm trees results in lower wood density. The growth of $B$. riedelianum is slow to moderate (Carvalho 2004). The highest volumetric productivities were mentioned by Garrido, Nogueira, and Garrido (1982) and Gurgel Filho, Moraes, and Garrido (1982) at 26 years old $\left(12 \mathrm{~m}^{3} \mathrm{ha}^{-1}\right.$ year-1 $^{-1}$ ), nearly twice that of our study (Table 3 ). However, our values were higher than those in other studies, with younger trees, reported for southern and southeastern Brazil, e.g., Carvalho (2004), but in analyses of mean annual, other factors should be considered, such as spacing, soil type and age of planting.

Anatomical differences are potential producers of variations in growth. Larger vessels were observed in Bauru, although in increment, Bauru did not differ statistically from Gália. Thus, higher growth of Bauru, especially compared to Alvorada do Sul, can be explained by higher potential of hydraulic conductivity which, as consequence, positively influences photosynthetic rate (Hacke, Sperry, \& Pittermann, 2005). Larger vessels conduct water more efficiently than narrower ones. In addition, narrower and less frequent rays in Alvorada do Sul compared to the other two provenances may have also contributed to lower growth. This result can be explained by rays which primarily consist of parenchyma cells which can store starch. According to Costa, Callado, Coradin, and Carmello-Guerreiro (2006), B. riedelianum is mobilized for cambial reactivation after a period of dormancy. According to Carvalho (2004), B. riedelianum is a deciduous species. Therefore, the process of growth resumption is accelerated. From April to September, Luiz Antônio experiences a water deficit (Longui et al., 2011). Thus, a smaller volume and frequency of rays can be a competitive disadvantage in growth for Alvorada trees. Sebbenn, Freitas, Zanatto, Moraes, and Moraes (2009) reported faster growth and higher survival rate. Longui et al. (2011) observed wider rays, in provenance tests of Gallesia integrifolia, also planted in Luiz Antônio.

Studying the potential of native species (Brazilian) for the production of sawn wood, Silva (2013) reported that $B$. riedelianum has medium need of thinning and is suitable for planting in high silt content soils. Moreover, we found no data about the presence or content of silt in soils of studied areas. Silva (2013) did not indicate the potential production cycle for B. riedelianum (wood density $730 \mathrm{~kg} \mathrm{~m}^{-3}$ ), but suggested about 45 years for Hymenaea courbaril $\left(750 \mathrm{~kg} \mathrm{~m}^{-3}\right)$ and at 25 years for Myroxylon peruiferum $\left(780 \mathrm{~kg} \mathrm{~m}^{-3}\right)$. In this context, we asked if $B$. riedelianum at 30 years of age would be ready for cutting. We emphasize that trees collected for the present study, presented dbh average $\approx 16 \mathrm{~cm}$, but many trees were over $20 \mathrm{~cm}$, and others reached dbh of $32 \mathrm{~cm}$ (Table 3). Although the tree trunk of B. riedelianum is usually straight, diameters found at 30 years old may not be suitable for cutting. Campbell (1999) reported that the ideal age for cutting can be determined by current annual increment (CAI), which measures how much the forest has grown in volume in the last year and mean annual increment (MAI), i.e., wood volume growing on one hectare of forest during one year on average since the forest has been planted. 
Campbell (1999) suggests that trees should be cut when CAI values are equal to MAI, when planting reaches the maximum wood volumetric production by area by year.

\section{Radial variation}

The most expected pattern pith-bark is an increase in density (physical property) and, consequently, an increase in mechanical properties since these are influenced by wood density, as well as an increase in fiber length and wall thickness, increase in vessel diameter and decrease in vessel frequency from pith to toward bark (Lachenbruch, Moore, \& Evans, 2011; Hoadley, 2000; Baas, Ewers, Davis, Wheeler, 2004). It was observed a positive correlation between density and shear parallel to the grain $(R=0.99$ and $\mathrm{P}=0.03)$ and between MOR and fiber length $(\mathrm{R}=0.99$ and $\mathrm{P}=0.04)$ in Alvorada do Sul. However, the expected pattern was not clearly noticed in B. riedelianum since a gradual increase was noted only in Gália for modulus of elasticity and in Bauru for compression parallel to the grain, both having positive correlations with radial position, as previously reported, in addition to fiber length, which gradually increased towards the bark in Gália. Other properties and anatomical characteristics did not show the typical radial pattern, as described by Lachenbruch et al. (2011).

In general, when considering the means values among properties in three radial positions, Alvorada do Sul presented more resistant wood when compared to Gália and Bauru. Also, values of density and compression in Alvorada were highest among the three provenances, while shear values did not differ from those of Bauru, and $\mathrm{MOE}$ and MOR values did not differ from those of Gália. Wood from Alvorada do Sul was the most homogeneous and absent of radial variation in six characteristics, including shear, MOE, width and frequency of ray, fiber diameter, and wall thickness. Gália did not vary in four variables, including shear, compression, fiber diameter and wall thickness. Bauru was the most heterogeneous wood, with no variation in three variables, all anatomical: vessel diameter, height and frequency of ray. Thus, Alvorada do
Sul is the provenance with the highest value in properties and homogeneity, whereas Gália and Bauru provenances show the greatest mean annual increment.

\section{Wood strength and Strength class}

We did not find many studies about wood structure or physical and mechanical properties of $B$. riedelianum. Consequently, we compared the values of our study with those described by Mainieri and Chimelo (1989), Carvalho (2004) and Lima et al. (2011). The lack of studies about wood quality in a homogeneous plantation with determined age and spacings is a drawback since that is the information that farmers need in order to cultivate $B$. riedelianum for commercial purposes.

The density values this population are close to those reported by Mainieri and Chimelo (1989), $0.84 \mathrm{~g} \mathrm{~cm}^{-3}$ at $15 \% \mathrm{MC}$, but those authors did not mention the origin or age of B. riedelianum. Lima et al. (2011) studied the same planting of B. riedelianum at 24 years old and found a basic density of $0.60 \mathrm{~g} \mathrm{~cm}^{-3}$ (near the pith) to $0.65 \mathrm{~g} \mathrm{~cm}^{-3}$ (close to the bark), and Alvorada do Sul $\left(0.66 \mathrm{~g} \mathrm{~cm}^{-3}\right)$, and Gália $\left(0.64 \mathrm{~g} \mathrm{~cm}^{-3}\right)$ provenances did not show differences between them. Apart from the methodology for density determination which differed from that of Lima, it is related to the age of tree samples collected. Therefore, higher growth tree promoted a higher density for Alvorada do Sul compared to the other two provenances. According to Mainieri et al. (1983), B. riedelianum wood is classified as heavy wood since it has specific gravity between 750 - 950 $\mathrm{kg} \mathrm{m}^{-3}$. According to Brunelli, Leal, and Longo, (1997), B. riedelianum wood can be used to manufacture furniture, because its wood presents light coloration, nice appearance and appropriate mechanical strength. We noted little or no variation in color between heartwood and sapwood, which is characteristic of B. Riedelianum. According to Carvalho (2004), sapwood is white in color or slightly yellowish, while heartwood is white-yellowish straw, darkening to uniform pale yellow.

The results for shear parallel to the grain $(16.70 \mathrm{MPa}$ 20.28 $\mathrm{MPa}$, means) were higher than those reported by 
Mainieri and Chimelo (1989), who described $13 \mathrm{MPa}$ for $B$. riedelianum green wood (above 20\% moisture), but the age was not mentioned. In our study, the tests were performed with samples at $12 \%$ EMC, and it indicates dry wood. The values of mechanical properties are lower when determined in green woods, as seen in several species tabulated by Kretschmann (2010). The results for compression parallel to the grain (44.89 $\mathrm{MPa}-54.11 \mathrm{MPa}$, means) were lower than those presented by Mainieri and Chimelo (1989) at $15 \%$ EMC (58.90 MPa), but since these did not have other information from the study cited above, it is not possible to establish a clearer comparison due to the facta that the present study used trees younger than those studied by Mainieri and Chimelo (1989).

According to NBR 7190 (ABNT, 1997), B. riedelianum wood falls into strength class $\mathrm{C} 40$, whereas the values of compression varied between 44.89 $\mathrm{MPa}$ to $54.11 \mathrm{MPa}$ in the pith of Gália and middle position of Alvorada do Sul, respectively. Zenid et al. (2009) state that the use of strength classes eliminates the need to specify wood species regarding mechanical strength, but the mechanical properties should be known ahead of time in order to categorize a given species. Besides, knowledge of species is also essential when it is necessary to use wood that is naturally resistant or permeable to preservative solutions, or when it is necessary to know the workability and decorativeness of wood.

For modulus of elasticity (MOE) and modulus of rupture (MOR), Mainieri and Chimelo (1989) reported MOE of 11493 in green wood and MOR of $137 \mathrm{MPa}$ at $15 \%$ moisture content. In this study values at $12 \%$ were higher for MOE (11659 MPa - $13942 \mathrm{MPa}$, means) and lower for MOR (116 MPa - $124 \mathrm{MPa})$. Here it is necessary to consider the difference in moisture content and the absence of other information from tree planting for woods which were tested and described by Mainieri and Chimelo (1989).

\section{CONCLUSIONS}

Variations in volume, properties and anatomy of wood occur among provenances. Alvorada do Sul shows lower growth in volume compared to Gália and Bauru. Alvorada do Sul wood presents higher strength and homogeneity than the other two provenances. Thus, Alvorada do Sul is the provenance with the highest value in properties and homogeneity, whereas Gália and Bauru provenances show the greatest mean annual increment.

Typical radial pattern, increase of the values from pith to the bark, is not observed for most wood characteristics, except MOE and fiber length in Gália and compression parallel to the grain in Bauru.

Based on compression parallel to the grain, 30-yearold B. riedelianum wood in a homogeneous planting has medium to high mechanical strength (reached a medium to upper strength class - C40), and as such, it is indicated for use in medium-sized structures and light civil construction, as well as the manufacture of furniture.

\section{ACKNOWLEDGEMENTS}

The authors thank Dirceu de Souza and Israel Luiz de Lima for fieldwork (Forestry Institute - IF), as well as Ailton de Lima Lucas (UNESP - Botucatu), Sonia Regina Godoi Campião, Yara Rose Weingartner Vianello and Juraci de Andrade Barbosa (Forestry Institute - IF) for laboratory assistance. We also thank the Programa de Pós-Graduação em Planejamento e Uso de Recursos Renováveis UFSCAR/Sorocaba for support in development of this study.

\section{REFERENCES}

Almeida, E. M. R., Toniato, M. T. Z., \& Durigan, G. (2011). Plano de Manejo da Estação Ecológica de Bauru. São Paulo: Instituto Florestal, Secretaria do Meio Ambiente.

Agência Nacional de Águas [ANA] (2017). Sistema de Informação Hidrológicas. Data of mean annual precipitation and temperature from January 1975 to December 1985. Retrieved from http://hidroweb.ana.gov.br.

Associação Brasileira de Normas Técnicas [ABNT] (1997). NBR 7190. Design of wooden structures (in Portuguese). Rio de Janeiro: ABNT.

Baas, P., Ewers, F. W., Davis, S. D., \& Wheeler, E. A. (2004). Evolution of xylem physiology. In Poole, I., Hemsley, A. (Eds.), Evolution of plant physiology (pp. 273-295). London: Elsevier Academic Press. 
Berlyn, G. P. \& Miksche, J. P. (1976). Botanical microtechnique and cytochemistry. Ames. USA: Iowa State University.

Bhering, S. B., Santos, H. G., Manzatto, C. V., Bognola, I., Carvalho, A. P., Potter, O., Aglio, M. L. D., Silva, J. S., Chaffin, C. E., \& Carvalho Junior, W. (2007). Mapa do solo do estado do Paraná. Rio de Janeiro: EMBRAPA.

Brunelli, A. A., Leal, J. J., \& Longo, F. G. (1997). Madeiras: material para o design. São Paulo: SCTDE.

Campbell, H. (1999). Forestry economics: principles and practice. Queensland: University of Queensland, School of Economics.

Carvalho, P. E. R. (2004). Pau-marfim (Balfourodendron riedelianum). Colombo: Embrapa Florestas.

Costa, C. G., Callado C. H., Coradin V. T. R., \& Carmello-Guerreiro, S. M. (2006). Xilema. In B. Appezzato-Da-Glória \& S. M. CarmelloGuerreiro, (Eds.). Anatomia Vegetal (127-154). Viçosa. Editora UFV.

Durigan, G., Figliolia, M. B., Kawabata, M., Garrido, M. A. O., \& Baitello, J. B. (1997). Sementes e mudas de árvores tropicais. São Paulo: Páginas \& Letras.

Garrido, M. A. O., Nogueira, J. C. B., \& Garrido, L. M. A. G. (1982). Características silviculturais do pau-marfim (Balfourodendron riedelianum Engl.). In: Congresso Nacional Sobre Essências Nativas. Campos do Jordão. Anais. São Paulo: Instituto Florestal. Publicado na Silvicultura. 16 A. (parte 2): 1081-1085.

Gurgel Garrido, L. M. A., Faria, H. H., Cruz, S. F., \& Palomo, M. (1997). Variabilidade genetica de caracteristicas silviculturais de Liquidambar styraciflua L. em teste de origens em Paraguacu Paulista-SP. Revista Instituto Florestal, 9(2), 125-132.

Gurgel Filho, O. A., Moraes, J. L., \& Garrido, L. M. A. G. (1982). Silvicultura de essências indígenas sob povoamentos homóclitos coetâneos experimentais. VI - Pau marfim (Balfourodendron riedelianum Eng.). In: Congresso Nacional Sobre Essências Nativas. Campos do Jordão. Anais. São Paulo: Instituto Florestal. Publicado na Silvicultura. 16 A. (parte 2): 867-872.

Hacke, U. G., Sperry, J. S., \& Pittermann, J. (2005). Efficiency versus safety tradeoffs for water conduction in angiosperm vessels versus gymnosperm tracheids. In N. M. Holbrook \& M. A. Zwienniecki (Eds.). Vascular transport in plants (333-354). Amsterdam: Elsevier Incorporated.

Harris, F. (2007). The effect of competition on stand, tree, and wood growth and structure in subtropical Eucalyptus grandis plantations ( $\mathrm{PhD}$ thesis). Southern Cross University, Lismore, NSW, Australia.

Higuchi, N. (1978). Tabelas de volume, para povoamentos nativos de canafistula (Leguminosae), cedro (Meliaceae), pau-marfim (Rutaceae) e canelas
(Lauraceae) no extremo oeste (Dissertação Mestrado). Universidade Federal do Paraná. Brasil.

Hoadley, B. (2000). Understanding wood: a craftsman's guide to wood technology. Newtown: Taunton Press.

IAWA Committee. (1989). International Association of Wood Anatomists. List microscope features of hardwood identification. LAWA Bulletin, 10(3), 219-332.

International Union for Conservation of Nature - IUCN. (1998). Americas Regional Workshop (Conservation \& Sustainable Management of Trees, Costa Rica, November 1996). Balfourodendron riedelianum. The IUCN Red List of Threatened Species. Retrieved from doi: 10.2305/IUCN.UK.1998.RLTS.T32987A9741568.en.

Johansen, D. A. (1940). Plant microtechnique. New York: McGraw- Hill.

Kretschmann, D. E. (2010). Mechanical properties of wood. In Ross R. (Ed.) Wood Handbook (5-1-5-46). Madison: U.S. Department of Agriculture, Forest Service.

King, D. A., Davies, S. J., Nur Supardi, M. N., \& Tan, S. (2005). Tree growth is related to light interception and wood density in two mixed dipterocarp forests of Malaysia. Functional Ecology, 19(3), 445-453. doi: 10.1111/j.1365-2435.2005.00982.x

Kollmann, F. \& Cote' W. A. (1968). Principles of wood science and technology. Berlin: Springer- Verlag.

Lachenbruch, B., Moore J. R., \& Evans, R. (2011). Radial variation in wood structure and function in woody plants, and hypotheses for its occurrence. In Meinzer F.C., Lanchenbruch, B., Dawson, T.E. (Eds.) Size-and age-related changes in tree structure and function (121164). New York: Springer.

Lima, I. L., Mastelin, S. M., Longui, E. L., Freitas, M. L. M., Romeiro, D., Zanatto, A. C. S., \& Florsheim, S. M. B. (2011). Densidade básica e dimensões celulares da madeira de Balfourodendron riedelianum em função da procedência e posição radial. Revista do Instituto Florestal, 23(2), 217-230.

Longui, E. L., Lima, I. L., Andrade, I. M., Freitas, M. L. M., Florsheim, S. M. B., Zanatto, A. C. S., \& Silva Júnior, F. G. (2011). Seed provenance influences the wood structure of Gallesia integrifolia. LAW A Journal, 32(3), 361-374.

Mainieri, C., Chimelo, J. P. (1989). Fichas de características das madeiras brasileiras. São Paulo: IPT - Instituto de Pesquisas Tecnológicas de São Paulo.

Pirani, J. R., Groppo, M., \& Dias, P. (2017). Rutaceae in Flora do Brasil 2020 em construção. Jardim Botânico do Rio de Janeiro. Retrieved from http://floradobrasil.jbrj.gov.br/reflora/floradobrasil/FB343. 
Madera y Bosques vol. 26, num. 1, e2611905 Spring 2020

Paula, J. E. \& Alvez, J. L. H. (2007). 897 madeiras nativas do Brasil: anatomiadendrologia, dendrometria-produção-uso. Porto Alegre: Cinco Continentes.

Rezende, M. A., Escobedo, J. F., \& Ferraz, E. S. B. (1988). Retratibilidade volumétrica e densidade aparente da madeira em função da umidade (in Portuguese). IPEF 39, 33 - 40.

Sebbenn, A. M., Freitas, M. L. M., Zanatto, A. C. S., Moraes, E., \& Moraes, M. A. (2007). Conservação ex situ e pomar de sementes em banco de germoplasma de Balfourodendron riedelianum. Revista do Instituto Florestal, 19(2), 101-112.

Sebbenn, A. M., Freitas, M. L. M., Zanatto, A. C. S., Moraes, E., \& Moraes, M. A. (2009). Comportamento da variação genética entre e dentro de procedências e progênies de Gallesia integrifolia Vell. Moq. Para caracteres quantitativos. Revista do Instituto Florestal, 21(2), $151-163$.

Silva, C. C. (2013). Potencial de espécies nativas para a produção de madeira serrada em plantios de restauração florestal (Dissertação Mestrado). Escola Superior de Agricultura "Luiz de Queiroz", Piracicaba, Brasil.

Zanatto, A. C. S., Leonel, C., Thomaziello, S., \& Oliveira, E. M. (2013). Plano de manejo da Estação Ecológica de Jataí. São Paulo: Fundação Florestal, Secretaria do Meio Ambiente.
Zenid, G. J., Romagnano, L. F. T., Nahuz, M. A. R., \& Miranda, M. J. A. C., Ferreira, O. P., Brazolin, S. (2009). Madeira: uso sustentável na construção civil. São Paulo: Instituto de Pesquisas Tecnológicas de São Paulo.

Received: 7 December 2018

Accepted: 8 August 2019

Published: 11 April 2020

This paper must be cited as:

Assad, A. A. V, Ballarin, A. W., Freitas, M. L. M., \& Longui, E. L. (2020). Effect of provenances on wood properties Balfourodendron riedelianum. Madera y Bosques, 26(1), e2611905. doi: 10.21829/myb.2020.2611905

Madera y Bosques by Instituto de Ecología, A.C. is distributed under a Creative Commons Licence Attribution-NonCommercial-ShareAlike $\quad 4.0$ Internacional. 